\title{
Batch studies on nitrate removal from potable water
}

\author{
A Darbi ${ }^{1}, \mathrm{~T}$ Viraraghavan ${ }^{2 \star}, \mathrm{R}$ Butler $^{3}$ and D Corkal ${ }^{4}$ \\ ${ }^{1}$ Faculty of Engineering, University of Regina, Regina, Saskatchewan, Canada \\ $2^{*}$ Faculty of Engineering, University of Regina, Regina, Saskatchewan, S4S-0A2, Canada \\ ${ }^{3}$ Prairie Farm Rehabilitation Administration, Winnipeg, Manitoba Canada \\ ${ }^{4}$ Prairie Farm Rehabilitation Administration, Saskatoon, Saskatchewan, Canada
}

\begin{abstract}
A sulphur/limestone autotrophic denitrification process was used to achieve the biological removal of nitrate from groundwater. The feasibility of the system was evaluated under anaerobic conditions using laboratory-scale batch reactors. The optimum sulphur/ limestone ratio was determined to be 1:1 (wt/wt). Different initial nitrate-nitrogen concentrations $(94,57$, and $10 \mathrm{mg} \mathrm{NO}-\mathrm{-N} / \mathrm{l})$ were used during the batch tests to examine nitrate removal efficiencies. The results showed that the higher the initial concentration, the longer it takes before nitrate removal commences. Both total suspended solid (TSS) and mean size of particles increased with time, which may be related to bacterial growth in the system.
\end{abstract}

\section{Introduction}

Many water agencies are faced with problems related to high concentrations of nitrate in groundwater. Evidence suggests that in many parts of the world, agricultural practices may be a contributing factor. In some instances, high concentrations may be due to natural background levels or other causes such as on-site wastewater disposal systems. The farming communities in Canada are well aware of the problem and are taking steps to address this issue with full support of local, provincial and federal agencies. Mitigative measures almost always include adjusting land management practices to prevent nitrate accumulation in aquifers. However, where high nitrate levels exist, water treatment dealing with the problem may also be required. Nitrate can cause a significant health problem to humans. Methemoglobinemia is the most common among infants and is potentially the most serious complication of nontherapeutic, excessive nitrate and nitrite exposure. A study made by Weyer et al. (2001) showed that for all cancers there was no association with increasing nitrate in drinking water, nor were there clear and consistent associations for non-Hodgkin lymphoma; leukemia; melanoma; or cancers of the colon, breast, lung, pancreas, or kidney but there were positive associations for bladder cancer.

Because of these possible health impacts, a maximum acceptable concentration of $10 \mathrm{mg} / \mathrm{l}$ as nitrate-nitrogen is specified in Guidelines for Canadian Drinking Water Quality (1996).

A wide range of physico-chemical processes such as ion exchange, reverse osmosis, electrodialysis, chemical denitrification and biological denitrification processes are currently being developed for removal of nitrate from drinking water, essentially for large-scale water treatment plants (Kapoor and Viraraghavan, 1997). Regarding drinking water denitrification numerous substrates have been evaluated including methanol, ethanol, acetic acid, methane, carbon monoxide, hydrogen and various sulfur compounds (Gayle et al., 1989).

There is no specific nitrate removal system in operation in Canada as part of municipal drinking water treatment. Only limited

\footnotetext{
* To whom all correspondence should be addressed.

誼(306) 585-4094; fax: (306)585-4855; e-mail: t.viraraghavan@uregina.ca Received 11 October 2001; accepted in revised form 4 April 2002.
}

research on nitrate removal from drinking water has been conducted in Canada.

Autotrophic bacteria such as Thiobacillus denitrificans and Thiomicrospira denitrificans are capable of reducing nitrate to nitrogen gas. The energy source of autotrophic denitrifying microorganisms is derived from oxidation-reduction reactions with elements such as hydrogen or sulphur as the electron donor. Autotrophic denitrifiers utilise inorganic carbon compounds (such as $\mathrm{CO}_{2}, \mathrm{HCO}_{3}^{-}$) as their carbon source (Baalsruud and Baalsruud, 1954; Bachelor and Lawrence, 1978a,b,c; Claus and Kutzner, 1985). In contrast, no organic carbon is needed as in heterotrophic denitrification. Another advantage of autotrophic denitrificans is that reproduction rate is low resulting in less sludge production and minimises the handling processes. Autotrophic denitrification has been divided into hydrogen-based and sulphur-based processes. Autotrophic organisms such as Micrococcus denitrificans are capable of reducing nitrate to nitrogen while oxidising hydrogen to water. Gross et al. (1986) developed a process known as DENITROPUR using hydrogenotrophic micro-organisms present in the aquifer. A synthetic material was used as a biomass support for a fixed bed reactor. The DENITROPUR plant at Mönchengladbach, Germany, was constructed to treat $2384 \mathrm{~m}^{3} / \mathrm{d}$ of groundwater. The reactor operated at a loading rate of $0.12 \mathrm{~kg} \mathrm{~N} / \mathrm{m}^{3} \cdot \mathrm{d}$, reduced the nitrate concentration from 75 to less than $1 \mathrm{mg} / \mathrm{l}$. Although treatment has been very successful, it is quite expensive due to costs of generating and handling hydrogen gas. Therefore, much more attention has been concentrated recently on sulphurbased autotrophic denitrification. Flere and Zhang (1998) conducted a study of nitrate removal by using sulphur and limestone autotrophic denitrification. The influent $\mathrm{NO}_{3}^{-}-\mathrm{N}$ concentration was $30 \mathrm{mg} / \mathrm{l}$ with a hydraulic retention time of $30 \mathrm{~d}$. It was observed that nitrate removal efficiency was 95 to $100 \%$ with alkalinity control and 80 to $85 \%$ without alkalinity control.

The sulphur/limestone process for groundwater nitrate removal is based on autotrophic denitrification by Thiobacillus denitrificans, where nitrate is converted into nitrogen gas under anoxic conditions. Sulphur is used as electron donor and limestone is used to maintain the $\mathrm{pH}$, while sulphur is converted to sulphate and biomass is produced (empirical cell mass formula $\mathrm{C}_{5} \mathrm{H}_{7} \mathrm{O}_{2} \mathrm{~N}$ ). Guidelines for Canadian Drinking Water Quality (1996) stipulates a maximum 
acceptable concentration of sulphate in drinking water at 500 $\mathrm{mg} / \mathrm{l}$. The sulphate concentration in the finished drinking water depends on the initial nitrate concentration to be removed, retention time and the sulphur/limestone ratio. 1987)

The reaction proceeds as follows (Schippers and Kruithof,

$$
\begin{aligned}
& 55 \mathrm{~S}+50 \mathrm{NO}_{3}^{-}+38 \mathrm{H}_{2} \mathrm{O}+20 \mathrm{CO}_{2}+4 \mathrm{NH}^{+} \\
& \rightarrow 4 \mathrm{C}_{5} \mathrm{H}_{7} \mathrm{O}_{2} \mathrm{~N}+25 \mathrm{~N}_{2}+55 \mathrm{SO}^{2-}{ }_{4}+64 \mathrm{H}^{+}
\end{aligned}
$$

In this study sulphur/limestone autotrophic denitrification (SLAD) process for nitrate removal from drinking water under high nitrate concentrations was examined. Different sulphur/limestone ratios have been suggested in the literature. Batch experiments were used to define the optimum sulphur/limestone ratio for nitrate removal.

\section{Objective of the study}

The main objective of the study was to evaluate the sulphur limestone autotrophic denitrification (SLAD) system for nitrate removal from drinking water. The study involved the following tasks:

- determining the optimum sulphur:limestone $(\mathrm{S}: \mathrm{L})$ ratio by evaluating the performance of different $\mathrm{S}: \mathrm{L}$ ratios through batch tests

- evaluating the result of batch studies by monitoring the nitrate, nitrite, sulphate production, and $\mathrm{pH}$.

\section{Materials and methods}

\section{Thiobacillus denitrificans culture}

Thiobacillus denitrificans (ATCC 23642) was grown in a medium as described by Lampe and Zhang (1996). The composition of the medium was $6 \mathrm{~g} / \mathrm{l} \mathrm{Na} \mathrm{S}_{2} \mathrm{O}_{3} .5 \mathrm{H}_{2} \mathrm{O}, 3 \mathrm{~g} / \mathrm{l} \mathrm{KNO}_{3}, 1.5 \mathrm{~g} / \mathrm{l} \mathrm{NaHCO} \mathrm{NaH}_{3}, 1.5$ $\mathrm{g} / \mathrm{l} \mathrm{Na} \mathrm{HPO}_{4}, 0.3 \mathrm{~g} / \mathrm{KH}_{2} \mathrm{PO}_{4}, 0.4 \mathrm{~g} / \mathrm{l} \mathrm{MgSO} \mathrm{Mg}_{4} .7 \mathrm{H}_{2} \mathrm{O}$ and $1 \mathrm{ml} / \mathrm{l}$ trace nutrient solution. The composition of the trace nutrient solution was $56.25 \mathrm{mg} / \mathrm{l} \mathrm{K} \mathrm{HPO}_{4}, 5.74 \mathrm{mg} / \mathrm{l} \mathrm{NH} \mathrm{N}_{4} \mathrm{Cl}, 1 \mathrm{mg} / \mathrm{l} \mathrm{MgCl} .6 \mathrm{H}_{2} \mathrm{O}$, $1 \mathrm{mg} / \mathrm{l} \mathrm{MnSO} \mathrm{O}_{4} \cdot \mathrm{H}_{2} \mathrm{O}, 1 \mathrm{mg} / \mathrm{CaCl}_{2}$ and $1 \mathrm{mg} / \mathrm{FeCl}_{2} \cdot 6 \mathrm{H}_{2} \mathrm{O}$. The stock culture was inoculated into 11 of medium, flushed with nitrogen and incubated at room temperature for 7 to $14 \mathrm{~d}$.

\section{Batch tests}

\section{Effects of different sulphur/limestone ratios}

Batch tests were initially conducted to determine the optimum ratio of S:L for the SLAD process. The sulphur (100\% pure) was obtained from Consumers' Co-operative Refinery Ltd., Regina, Saskatchewan. Limestone was purchased from Regal Flooring Ltd., Regina, Saskatchewan. The grain size of sulphur and limestone used ranged from 2.38 to $4.76 \mathrm{~mm}$. Initial nitratenitrogen concentration of $27 \mathrm{mg} \mathrm{NO}{ }^{-}-\mathrm{N} / \mathrm{l}$ was achieved using $0.195 \mathrm{~g} \mathrm{KNO}_{3} /$ l. The nitrate solutions were prepared using both deionised and tap water. Tap water characteristics are shown in Table 1. The tap water had residual chlorine concentrations of $0.4 \mathrm{mg} / \mathrm{l}$; it was not dechlorinated. The experiments were conducted under anaerobic conditions, established by flushing the contents of the $250 \mathrm{ml}$ bottles with nitrogen gas for $5 \mathrm{~min}$. Each batch test bottle typically contained $10 \mathrm{~g}$ (total mass) of sulphur and/or limestone in different ratios such as 1:1, 2:1,3:1,1:2,1:3, and 1:0, and inoculated with $15 \mathrm{ml}$ of the Denitrificans culture in $200 \mathrm{ml}$ of the nitrate solutions. Nitrate, nitrite, sulphate and $\mathrm{pH}$ of the batch test solutions were periodically measured. An optimum S:L ratio was selected

\begin{tabular}{|l|c|}
\hline \multicolumn{2}{|c|}{ TABLE 1 } \\
Water characteristics \\
\hline Parameters & Concentrations \\
\hline $\mathrm{pH}$ & 7.5 \\
$\mathrm{Conductivity} \mathrm{mS} / \mathrm{cm}$ & 534 \\
$\mathrm{NO}_{3}^{-}-\mathrm{N}, \mathrm{mg} / \mathrm{l}$ & 0 \\
$\mathrm{NO}_{2}^{-}-\mathrm{N}, \mathrm{mg} / \mathrm{l}$ & 0 \\
$\mathrm{Cl}^{-}, \mathrm{mg} / \mathrm{l}$ & 18 \\
$\mathrm{SO}_{4}^{2-} \mathrm{mg} / \mathrm{l}$ & $185-200$ \\
$\mathrm{Hardness}_{\mathrm{m}} \mathrm{mg} / \mathrm{l}$ as $\mathrm{CaCO}_{3}$ & 232 \\
$\mathrm{Alkalinity,} \mathrm{mg/l} \mathrm{as} \mathrm{CaCO}_{3}$ & 124 \\
$\mathrm{TDS}, \mathrm{mg} / \mathrm{l}$ & 230 \\
\hline
\end{tabular}

based on high nitrate removal, low sulphate production and nearneutral $\mathrm{pH}$.

Effect of different initial nitrate-nitrogen concentration Using a tap water and under anaerobic conditions three initial $\mathrm{NO}_{3}$ $-\mathrm{N}$ concentrations were used $\left(94,57\right.$ and $\left.10 \mathrm{mg} \mathrm{NO}_{3}^{-}-\mathrm{N} / \mathrm{l}\right)$ to simulate both heavily and moderately nitrate-contaminated groundwaters. An S:L ratio of $1 / 1$ was used in the experiments. Nitrate, nitrite, sulphate and $\mathrm{pH}$ were measured throughout the experiments.

\section{Particle counting}

Tap water was used for conducting this experiment with an initial concentration of $17 \mathrm{mg} \mathrm{NO}_{3}^{-}-\mathrm{N} / \mathrm{l}$. After preparing the solutions and inoculating with $15 \mathrm{ml}$ of the autotrophic denitrificans culture, measurements were taken using a Spectrex laser particle counter model PC-2000 to measure the count and mean size of the particles.

The aim of the experiment was to compare the nitrate removal with total suspended solids (TSS) and mean size of solids because both could be related to bacterial growth in the system.

\section{Analytical methods}

Nitrate-nitrogen $\left(\mathrm{NO}_{3}{ }^{-} \mathrm{N}\right)$, nitrite-nitrogen $\left(\mathrm{NO}_{2}^{-}-\mathrm{N}\right)$, and sulphate $\left(\mathrm{SO}_{4}^{2-}\right)$ were determined by Dionex 600 Ion Chromatography (IC) equipped with CD25 conductivity detector. The Dionex Ionpac AS 17 column was controlled at $35^{\circ} \mathrm{C}$ in a LC25 chromatography oven. The sample was filtered within the sample holder using the AS40 automated sampler, which was used with the IC system. The $\mathrm{pH}$ of all samples was tested using a Fisher Accumet model $600 \mathrm{pH}$ meter. Dissolved oxygen was measured using a YSI 52 dissolved oxygen meter.

\section{Results and discussion}

\section{Batch study}

One of the primary reasons for conducting the batch tests was to identify the optimum ratio of elemental sulphur to limestone. Figure 1 shows the effect of the different S:L (mass:mass) ratios on nitrate-nitrogen removal efficiency, $\mathrm{pH}$ and sulfate production. The nitrate solution was prepared with deionised water in this experiment. An S:L ratio of 1:0 showed high nitrate removal efficiencies, but was not considered as the optimum ratio because of its low $\mathrm{pH}(<6)$. When limestone was being used as $\mathrm{pH}$ control a $\mathrm{pH}$ of \pm 8 was observed for all ratios and without limestone, the $\mathrm{pH}$ was found to decrease by two units. An S:L ratio of 3:1 also 


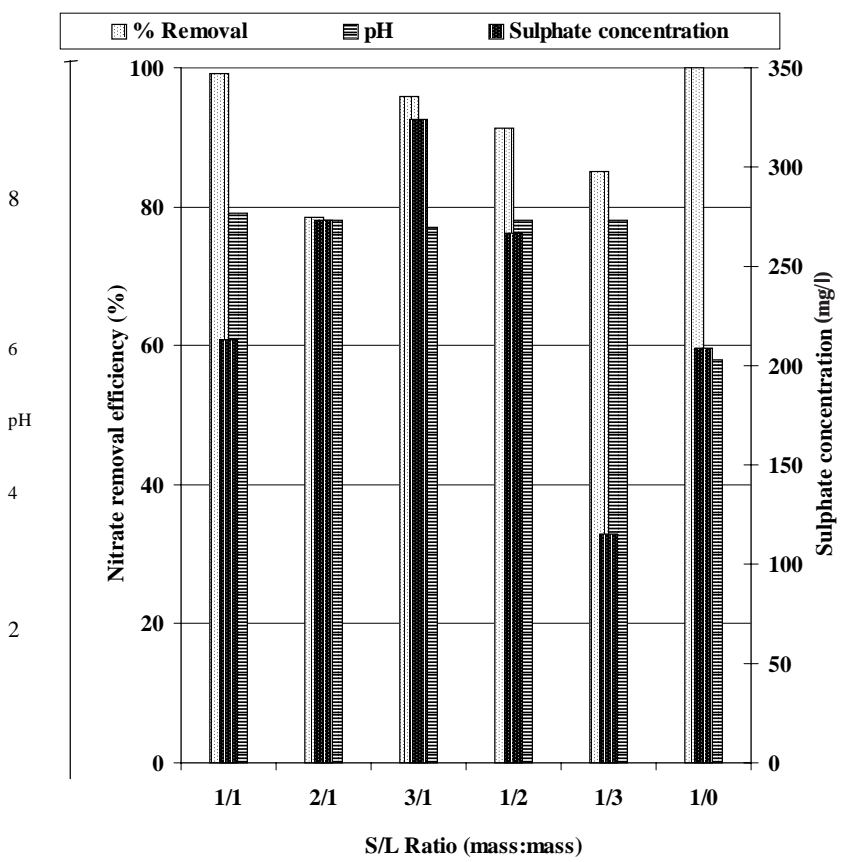

Figure 1

Effect of $S: L$ ratios on nitrate-nitrogen removal efficiency, $\mathrm{pH}$ and sulfate production (Deionised water with initial $\mathrm{NO}_{3}-\mathrm{N}=27 \mathrm{mg} / \mathrm{l}$ )

resulted in high nitrate removal efficiencies $(>95 \%)$, the sulphate production was also high. A ratio of 1:1 resulted in $98 \%$ nitrate removal and sulphate production was not high compared to other ratios examined. Figure 2 shows the different S:L ratios on nitratenitrogen removal efficiency, $\mathrm{pH}$ and sulphate production, where the nitrate solution was prepared with tap water. Ratios of 1:1, 1:0, 2:1 and 3:1 gave similar nitrate removal efficiencies. The $\mathrm{pH}$ was found to be approximately 7 under all ratios. Sulphate production for a 1:1 ratio was less compared to the other ratios.

In general, nitrate removal using tap water spiked with nitrate as a feed solution was higher than the nitrate removal using deionised water for all S:L ratios. Sulphate level was higher in the case of tap water because of the background sulphate of $200 \mathrm{mg} / \mathrm{l}$. It is likely that the tap water minerals provided the nutrient supply for bacterial growth resulting in better nitrate removal.

From both batch studies, it was found that a 1:1 ratio was optimal in achieving a high nitrate removal efficiency with a low sulphate production. An S:L ratio of 1:1 (mass/mass) was also observed by Sikora and Keeney (1976) and an S:L ratio 1:1 (v/v) was indicated by Schippers and Kruithof (1987) in their studies for optimal nitrate removal. However, S:L ratios of 1:2, 1:1 and 2:1 gave the same results with respect to nitrate removal capacities in a study made by Hoek et al. (1992). Zhang and Lampe (1999) reported that the optimum S:L ratio was $3: 1(\mathrm{v} / \mathrm{v})$. These differences may possibly be due to differences in experimental conditions and characteristics of sulphur and limestone (particle size, etc.).

Figure 3 shows the effect of different initial nitrate-nitrogen concentrations on nitrate removal efficiencies in the batch reactors. It can be seen that, with an increase in initial concentration, there was an increase in the reaction time required to achieve a high removal. In addition, no nitrate removal was achieved during the initial hours of the batch tests. Steady nitrate removals were observed subsequent to the lag period (Fig. 3). It can also be seen that the initial lag period before the onset of nitrate removal was dependent on the initial nitrate concentration, i.e. higher the initial concentration, the longer it took before the start of nitrate removal.

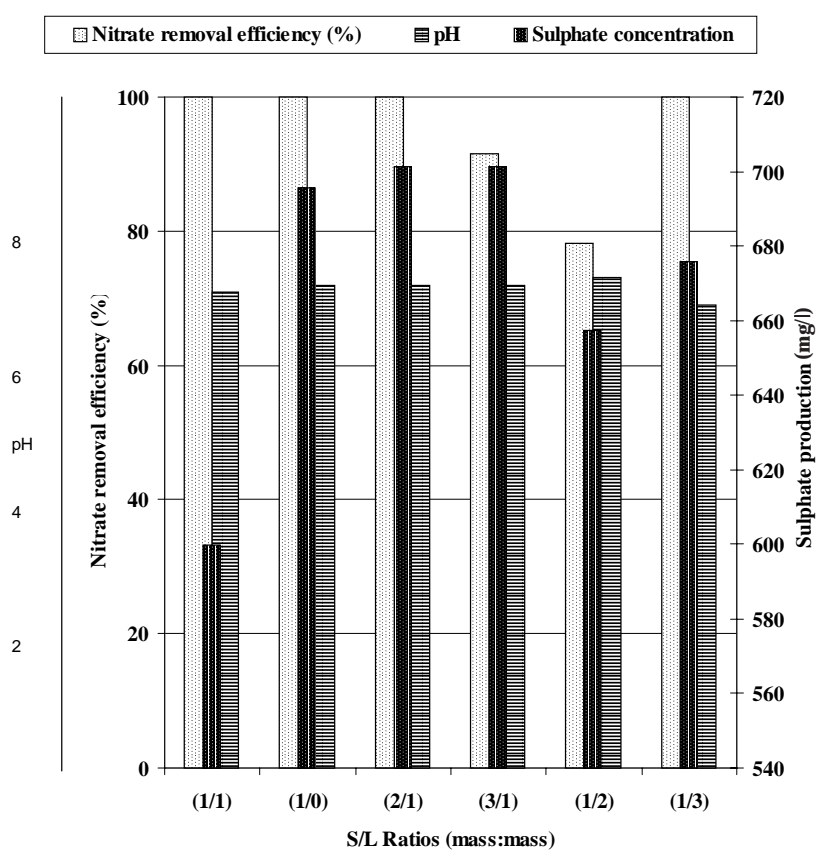

Figure 2

Effect of S:L ratios on nitrate-nitrogen removal efficiency, $\mathrm{pH}$ and sulfate production (Tap water with initial $\mathrm{NO}_{3}-\mathrm{N}=7 \mathrm{mg} / \mathrm{l}$ )

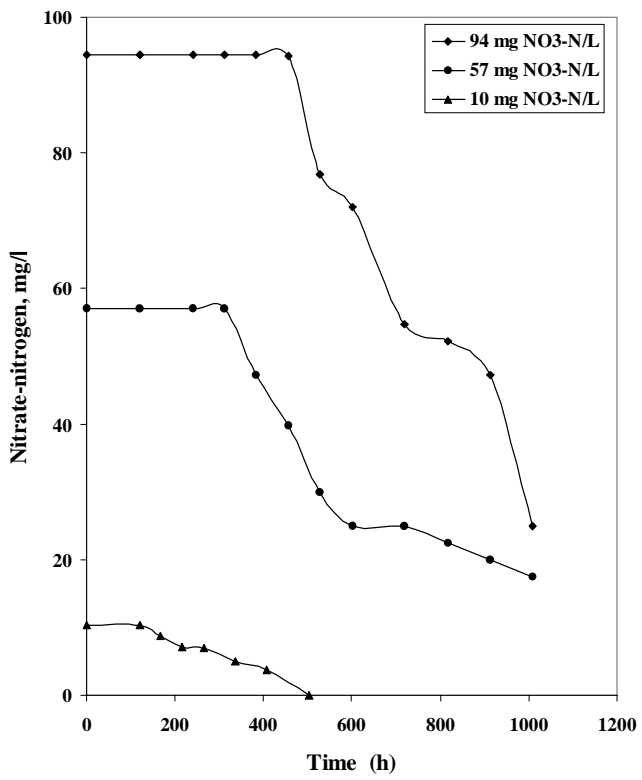

Figure 3

Variations of nitrate-nitrogen with time in batch reactors for different initial concentrations

Figure 4 shows the variation in sulphate concentration with time. Sulphate production increased with an increase in the initial nitrate-nitrogen concentration. The ratio of sulphate produced to nitrate removed was found to be 6:1. Koenig and Liu (1996) observed that for $1 \mathrm{mgNO}_{3}-\mathrm{N}$ reduced by autotrophic denitrification with sulphur particle size of 2.8 to $5.6 \mathrm{~mm}, 7.89 \mathrm{mg} \mathrm{SO}-$ was produced. The results showed that the nitrite- nitrogen concentration did not exceed $0.6 \mathrm{mg} \mathrm{NO}_{2}^{-}-\mathrm{N} / \mathrm{l}$ for any initial nitrate-nitrogen concentration.

Figure 5 shows that both TSS and mean size increased with time. The initial nitrate nitrogen concentration in the experiment 
was $17 \mathrm{mg} / \mathrm{l}$ reached less than $1 \mathrm{mg} / \mathrm{l}$ at $530 \mathrm{~h}$. The increase in the TSS and the mean size could be related to bacterial growth. There is a need for further treatment for separation of bacterial cells and disinfection of the water for drinking purposes.

Batch runs were not repeated; therefore, statistical analysis of the data is not possible. Although such data are usually questionable to some extent, the pattern of results showed in a convincing manner that autotrophic denitrification was evident.

\section{Conclusions}

The study showed that the SLAD process was a simple and reliable treatment process for removal of nitrate that could have an application to nitrate removal from groundwater. Batch test results indicated that 1:1 was the optimum S:L ratio based on nitrate removal, sulphate production and $\mathrm{pH}$.

As the nitrate concentration increased, more time was needed to achieve a high percentage of removal; on the other hand, TSS and mean size of solids increased with time, which may be related to the bacterial growth in the system. Further treatment such as disinfection is needed in order to use the water for drinking purposes.

\section{Acknowledgement}

The authors would like to thank the Prairie Farm Rehabilitation Administration (PFRA) for their support of the project. The research project was a collaborative venture. Funding was contributed by the "Canada-Saskatchewan Agri-Food Innovation Fund".

\section{References}

BAALSRUUD K and BAALSRUUD KS (1954) Studies on Thiobacillus denitrificans. Arch. Mikrobiol. $2034-62$.

BACHELOR B and LAWRENCE AW (1978a) A kinetic model for autotrophic denitrification using element sulfur. Water Res. 121075 1084.

BACHELOR B and LAWRENCE A W (1978b) Autotrophic denitrification using element sulfur. J. Water Pollut. Control Fed. 50 1986-2001.

BACHELOR B and LAWRENCE AW (1978c) Stoichiometry of autotrophic denitrification using element sulfur. In: Rubin AJ (ed.) Chemistry of Wastewater Technology. Ann Arbor Science Publishers, Ann Arbor, MI. 421-440.

CLAUS G and KUTZNER HJ (1985) Physiology and kinetics of autotrophic denitrification by Thiobacillus denitrificans. Appl. Microbiol. Biotechnol. 22 283-288.

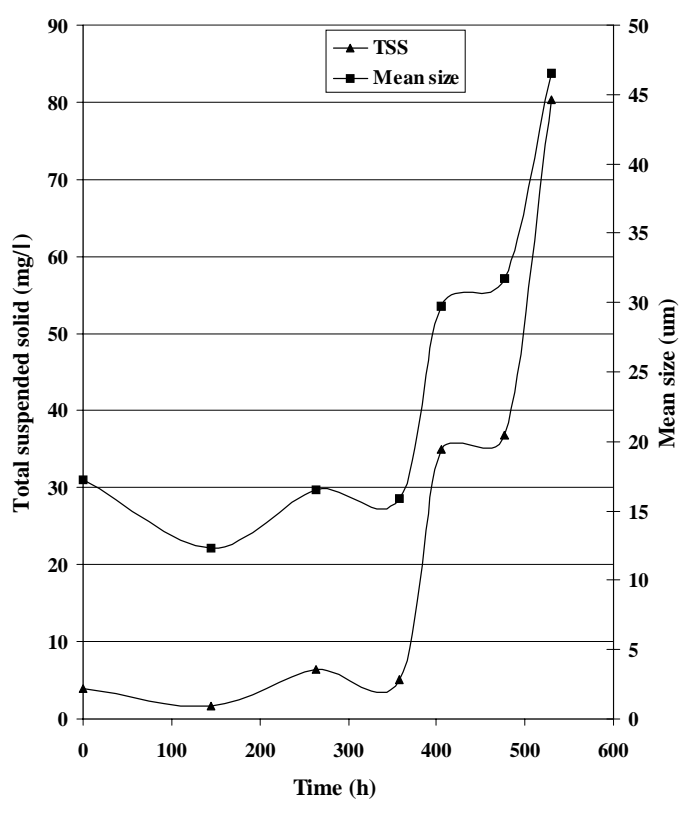

Figure 5

Variations of total suspended solids and mean size with time (initial nitrate-nitrogen concentration $=17 \mathrm{mg} / \mathrm{l}$ )

FLERE JM and ZHANG TC (1998) Remediation of nitrate contaminated surface water using sulfur and limestone autotrophic denitrification. Water Resources and the Urban Environment-98. 1998 Natl .Conf. on Environ. Eng. American Society of Civil Eng., New York, N.Y.

GAYLE BP, BOARDMAN GD, SHERREARD JH and BENOIT RE (1989) Biological denitrification of water. J. Environ. Eng. 115 (5) 930-943.

GROSS H, SCHNOOR G and TREUTER K (1986) Nitrate removal from groundwater by autotrophic microorganisms. Water Supply 4 11-21.

GUIDELINES FOR CANADIAN DRINKING WATER OUALITY (1996) Prepared by Federal-Provincial Subcomittee on Drinking Water of the Federal-Provincial Advisory Committee on Environmental and Occupational Health. Published by authority of Minister of National Health and Welfare ( $4^{\text {th }}$ edn.)

HOEK JP VAN DER, HIJNEN WAM, BENNEKOM VAN CA and MIJNARENDS B J (1992) Optimization of the sulfur-limestone process for nitrate removal from groundwater. Aqua 41 (4) 209-218.

KAPOOR A and VIRARAGHAVAN T (1997) Nitrate removal from drinking water-review. J. Environ. Eng. 123 (4) 371-380.

KOENIG A and LIU LH (1996) Autotrophic denitrification of landfill leachate using elemental sulphur. Water Sci. Technol. 34 469-476.

LAMPEDG and ZHANG TC (1996) Evaluation of sulfur-based autotrophic denitrification. Proc. HSRC/WERC Joint Conf. on Environ, May 2123. 444-458.

SCHIPPERS CJ and KRUITHOF CJ (1987) Removal of nitrate by slow sulfur/limestone filtration. Aqua 5 274-280.

SIKORA LJ and KEENEY DR (1976) Evaluation of sulfur-Thiobacillus denitrificans nitrate removal system. J. Environ. Quality 5 (3) 298303.

WEYER PJ, CERHAN JR, KROSS BC, HALLBERG GR, KANTAMNENI J, BREUER G, JONES MP, ZHENG W and LYNCH CF (2001) Municipal drinking water nitrate level and cancer risk in older women: The Iowa Women's Health Study. Epidemiol. 12 (3) 327-338.

ZHANG TC and LAMPE DG (1999) Sulfur: Limestone autotrophic denitrification processes for treatment of nitrate contaminated water: Batch experiments. Water Res. 33 (3) 599-608. 